\title{
INFLUENCES OF PEER SUPPORT GROUP AND PSYCHOSOCIO- ECONOMIC DETERMINANTS ON TREATMENT COMPLIANCE IN HIV/AIDS PATIENTS IN SRAGEN, CENTRAL JAVA
}

\author{
Yusuf Bachtiyar Lobisi), Bhisma Murti'), Hanung Prasetya') \\ ${ }^{1)}$ Masters Program in Public Health, Universitas Sebelas Maret \\ ${ }^{2)}$ School of Health Polytechnics, Ministry of Health Surakarta
}

\begin{abstract}
Background: Adherence to treatment is important to reduce viral replication, improve clinical and immunological conditions, reduce the risk of developing ARV resistance, and reduce the risk of HIV transmission. Peer support is suspected to be one of the factors driving drug intake adherence in patients with chronic disease. This study aimed to examine the influences of peer support and psychosocio-economic determinants on treatment compliance in HIV/AIDS patients.

Subjects and Method: This was a case control design study conducted in Sragen, Central Java, Indonesia. A sample of 200 people with HIV/AIDS (PLWH) was selected by fixed disease sampling. The dependent variable was treatment compliance. The independent variables were knowledge toward HIV/AIDS, perceived benefit, perceived belief, perceived threat, perceived susceptibility, perceived seriousness, perceived barrier, attitude, indirect experience, family support, and peer support. The data were obtained from medical record and questionnaire. The data were analyzed by a multiple logistic regression run on Stata 13.

Results: Treatment compliance increased with strong peer support $(b=1.34 ; 95 \% \mathrm{CI}=$ 0.31 to $2.38 ; \mathrm{p}=0.011)$, strong family support $(\mathrm{b}=1.09 ; 95 \% \mathrm{CI}=0.16$ to $2.02 ; \mathrm{p}=0.021$ ), knowledge toward HIV/AIDS $(\mathrm{b}=1.65 ; 95 \% \mathrm{CI}=0.67$ to $2.64 ; \mathrm{p}=0.001)$, high perceived benefit $(b=1.23 ; 95 \% \mathrm{CI}=0.28$ to $2.18 ; \mathrm{p}=0.011)$, perceived belief $(\mathrm{b}=2.05 ; 95 \% \mathrm{CI}=0.98$ to $3.12 ; \mathrm{p}<0.001)$, and high perceived threat $(\mathrm{b}=1.22 ; 95 \% \mathrm{CI}=0.30$ to $2.13 ; \mathrm{p}=0.009)$. Treatment compliance decreased with negative attitude $(\mathrm{b}=-2.47 ; 95 \% \mathrm{CI}=-3.58$ to -1.37 ; $\mathrm{p}<0.001)$, low perceived susceptibility $(\mathrm{b}=-1.26 ; 95 \% \mathrm{CI}=-2.24$ to $-0.27 ; \mathrm{p}=0.012)$, low perceived seriousness $(\mathrm{b}=-1.11 ; 95 \% \mathrm{CI}=-2.06$ to $-0.16 ; \mathrm{p}=0.021)$, high perceived barrier $(b=-1.76 ; 95 \% \mathrm{CI}=-2.81$ to $-0.70 ; \mathrm{p}=0.001)$, and indirect experience $(\mathrm{b}=-1.10 ; 95 \% \mathrm{CI}=-$ 2.05 to $-0.14 ; \mathrm{p}=0.024)$.

Conclusion: Treatment compliance increases with strong peer support, strong family support, high knowledge toward HIV/AIDS, high perceived benefit, perceived belief, and high perceived threat. Treatment compliances decrease with negative attitude, low perceived susceptibility, low perceived seriousness, high perceived barrier, and indirect experience.
\end{abstract}

Keywords: HIV/AIDS, treatment compliance, peer support, psychosocial economy

Correspondence: Yusuf Bachtiyar Lobis. Masters Program in Public Health, Universitas Sebelas Maret. Jl. Ir. Sutami 36A, Surakarta 57126, Central Java. Email: bachtiyaro3@gmail.com. Mobile: +628111388841.

The $7^{\text {th }}$ International Conference on Public Health Solo, Indonesia, November 18-19, $2020 \mid 170$ https://doi.org/10.26911/the7thicph.02.59 